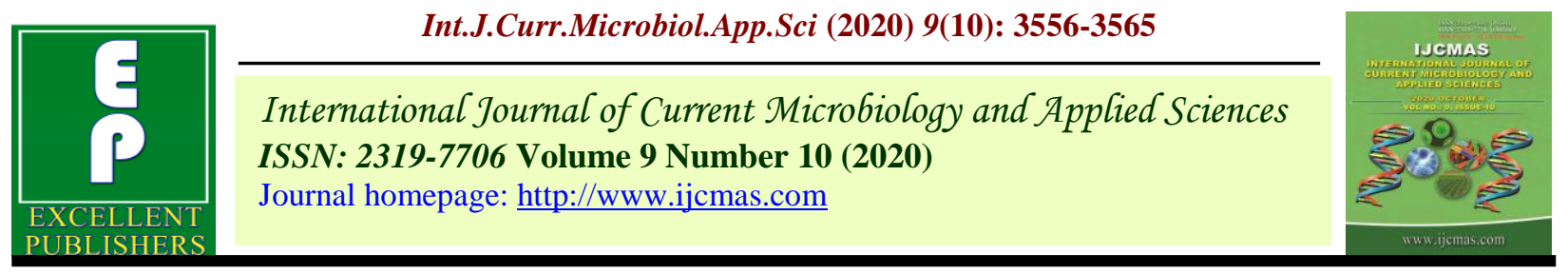

\title{
Influence of Plant Growth Hormones on Morphology and Yield of Patharchur (Coleus forskohlii (Willd) Briq)
}

\author{
A. K. Choudhary ${ }^{1 *}$, S. D. Upadhyaya ${ }^{2}$ and A. Sharma ${ }^{3}$ \\ ${ }^{1}$ Department of Plant Pathology, RAK College of Agriculture, Sehore 466001, Rajmata \\ Vijayaraje Scindia Krishi Vishwavidhyalya, Gwalior, Madhya Pradesh (MP) \\ ${ }^{2}$ Department of plant physiology, JNKVV, Jabalpur (M.P.), India \\ ${ }^{3}$ Department of Biological Science, $R$ D University, Jabalpur (M.P.), India \\ *Corresponding author
}

\section{A B S T R A C T}

\begin{tabular}{|l|}
\hline Keyw or d s \\
$\begin{array}{l}\text { Coleus, Cycocel, } \\
\text { ppm, Patharchur, } \\
\text { Hormones }\end{array}$ \\
\hline Article Info \\
\hline $\begin{array}{l}\text { Accepted: } \\
\text { 26 September } 2020 \\
\text { Available Online: } \\
\text { 10 October } 2020\end{array}$ \\
\hline
\end{tabular}

This study was conducted at A field experiment was carried out in the farmer field adjoining, RAK College of Agriculture, Sehore (Madhya Pradesh) during 2015 and 2016. Field experiment consisting of Plant Growth Hormones MH @ (100 and 150 ppm), Cycocel@ (500 and 1000 ppm), NAA @(50 and 100 ppm), GA3@(150 and 200 ppm) and water spray as control to study the influence of plant growth Hormones on morphology and yeild of Coleus forskohlii (Willd) Briq. The studies on morphological parameters, pooled data (2015 and 2016) at 150 day after transplanting (DAT) revealed that application of Cycocel @ 1000 ppm resulted in reduction of plant height $(\mathrm{cm})$ plant $^{-1}$ (51.11), increase fresh weight of plant $(\mathrm{g})$ plant $^{-1}$ (759.88) and dry weight of plant $(\mathrm{g})$ plant $^{-1}$ (104.33) followed by Cycocel @ 500 ppm respectively $(54.30,730.56,89.49)$ as campier to control $(63.35,530.24,63.78)$. The yield attributing parameters, at harvesting revealed that application of Cycocel @ 1000 ppm resulted in increased fresh weight of tuber (g) plant ${ }^{-1}(258.01)$, dry weight of tuber $(\mathrm{g})$ plant $^{-1}(42.93)$, and yield of tuber $(\mathrm{t}) \mathrm{ha}^{-1}$ (2.60) followed by Cycocel @ 500 ppm respectively $(240.27,253.56$ and 2.51$)$ as compare to control (205.18, 229.47 and 2.01).

\section{Introduction}

India stands good position among megabiodiverse countries in the world and known to be the storehouse of medicinal plants. Economic importance of medicinal plants is much more in India. Medicinal plants cultivated about 2,500 hectares in parts of Rajasthan, The importance of medicinal plant in health care results from the combination of secondary products present either in whole plant or in plant parts. These secondary products may be phytochemicals, steroids, biologically active compounds, alkaloids, antioxidants, flavonoids, pigments etc. and day by day the demand of these compounds is increasing. Coleus forskohlii (Willd) Briq. [syn. C. barbatus (Andr.) Benth] is a plant in Indian origin (Valdes et al., 1987) belonging to mint family Lamiaceae and grow perennially over tropical and sub tropical region of India, Pakistan, Sri Lanka, East 
Africa and Brazil Coleus forskohlii (Willd) Briq. [syn. C. barbatus (Andr.) Benth] (Patharchur) is an exclusive source of a labdane diterpene forskolin along with diversified chemical contents. Forskolin has wide spectrum of therapeutic value in varied health ailments. The crop has a great potential in future due to respected increase in demand for forskolin widely used in glaucoma, cardiac problem and also used in treatment of certain type of cancer (Shah et al., 1980). Plant growth regulators are group of naturally occurring, organic substances which effect growth processes at minute concentration, synthesized at one plant part and are capable of translocation to site of its action and regulating one or more morpho-physiological activity like vegetative growth and yield.

\section{Materials and Methods}

This study was conducted at A field experiment was carried out farmer field adjoining RAK College of Agriculture, Sehore (Madhya Pradesh) during the year 2015 and 2016. The experiment will be conduct under Randomized Block Design (R.B.D.) with nine treatments in three replication. There were eight treatments $\mathrm{MH}$ (100 and $150 \mathrm{ppm}$ ), Cycocel (500 and 1000 ppm), NAA (50 and $100 \mathrm{ppm}$ ), GA3 (150 and $200 \mathrm{ppm}$ ) and the water being the control. The plant growth regulators were sprayed in three stages viz cutting stage, vegetative stages and reproductive stage. The $\mathrm{k} 8$ variety cutting was transplanted in main field. The whole plot was divided into 3 block each representing the replication. Each block was then divided into unit plot of $3 \times 3 \mathrm{~m}$ size. Well rooted cuttings were transplanted at $60 \times 30 \mathrm{~cm}$ spacing. The experiment plot fertilized with NPK $40 \mathrm{~kg}, 60$ $\mathrm{kg}$ and $50 \mathrm{~kg} \mathrm{ha}^{-1}$ respectively. All the operations done regularly during growing season. Morphological parameters like, plant height, number of branches, fresh \& dry weight of plant and yield attributing character like number of tuber, fresh \& dry weight of tuber and yield of tuber were taken and observations recorded at 90,120, 150 day after transplanting and at the time of maturity. Finally mean data of the all characters were computed for statistical analysis as per standard procedure given by (Panse and Sukhtme, 1989).

\section{Results and Discussion}

\section{Morphological parameters}

\section{Plant height $(\mathrm{cm})$ plant $^{-1}$}

The data on the impact of different growth hormones on plant height of Coleus forskohlii at different stage of plant growth are presented in Table 1.

In the year 2015 at 90 DAT data showed that the height of the plant was observed to be in the range $53.07-45.30 \mathrm{~cm}$ as compared to control. The highest plant height 53.07 was recorded, treatment with Gibberellic acid $\left(\mathrm{GA}_{3}\right) 200 \mathrm{ppm}$ followed by Gibberellic acid $\left(\mathrm{GA}_{3}\right) 150 \mathrm{ppm} 51.54 \mathrm{~cm}$ and Naphthalene Acetic Acid (NAA) $50.41 \mathrm{~cm}$. lowest plant height $45.30 \mathrm{~cm}$ recorded with Cycocel (CCC) $1000 \mathrm{ppm}$. Plant height $49.34 \mathrm{~cm}$ was found in control as compared to other treatment.

In the year 2016 at 90 DAT data showed that the height of the plant was observed to be in the range $51.31-42.41 \mathrm{~cm}$ as compared to control. The highest plant height $51.31 \mathrm{~cm}$ was recorded treatment with Gibberellic acid $\left(\mathrm{GA}_{3}\right) 200 \mathrm{ppm}$ followed by Gibberellic acid $\left(\mathrm{GA}_{3}\right) 150 \mathrm{ppm} 51.08 \mathrm{~cm}$ and Naphthalene Acetic Acid (NAA) $49.93 \mathrm{~cm}$. lowest plant height $42.41 \mathrm{~cm}$ recorded with Cycocel (CCC), $1000 \mathrm{ppm}$. Plant height $47.18 \mathrm{~cm}$ was found in control as compared to other treatment. 
Pooled data was observed to be in the range $52.19-43.86 \mathrm{~cm}$ as compared to control. The highest plant height $52.19 \mathrm{~cm}$ was recorded treatment with Gibberellic acid $\left(\mathrm{GA}_{3}\right) 200$ ppm as compared to lowest plant height 43.86 $\mathrm{cm}$ with Cycocel (CCC), 1000 ppm. Plant height $48.26 \mathrm{~cm}$ was found in control as compared to other treatment.

In the year 2015 at 120 DAT, the height of the plant was observed to be in the range 66.22 $52.40 \mathrm{~cm}$ as compared to control. The highest plant height $66.22 \mathrm{~cm}$ was recorded treatment with Gibberellic acid $\left(\mathrm{GA}_{3}\right) 200$ ppm followed by Gibberellic acid $\left(\mathrm{GA}_{3}\right) 150 \mathrm{ppm}$ $65.46 \mathrm{~cm}$ and Naphthalene Acetic Acid (NAA) $65.20 \mathrm{~cm}$. lowest plant height 52.40 $\mathrm{cm}$ recorded with Cycocel (CCC), $1000 \mathrm{ppm}$. Plant height $63.87 \mathrm{~cm}$ was found in control as compared to other treatment.

In the year 2016 at 120 DAT, the height of the plant was observed to be in the range $61.06-$ $45.56 \mathrm{~cm}$ as compared to control. The highest plant height $61.06 \mathrm{~cm}$ was recorded treatment with Gibberellic acid $\left(\mathrm{GA}_{3}\right) 200 \mathrm{ppm}$ followed by Gibberellic acid $\left(\mathrm{GA}_{3}\right) 150 \mathrm{ppm}$ $60.34 \mathrm{~cm}$ and Naphthalene Acetic Acid (NAA) 59.63. lowest plant height $45.56 \mathrm{~cm}$ recorded with Cycocel (CCC), 1000 ppm. Plant height $56.80 \mathrm{~cm}$ was found in control as compared to other treatment.

Pooled data was observed to be in the range $63.64-48.98 \mathrm{~cm}$ as compared to control. The highest plant height $63.64 \mathrm{~cm}$ was recorded treatment with Gibberellic acid $\left(\mathrm{GA}_{3}\right) 200$ ppm as compared to lowest plant height 48.98 $\mathrm{cm}$ with Cycocel (CCC), 1000 ppm. Plant height $60.33 \mathrm{~cm}$ was found in control as compared to other treatment.

In the year 2015 at 150 DAT, the height of the plant was observed to be in the range 70.90 $54.08 \mathrm{~cm}$ as compared to control. The highest plant height $70.90 \mathrm{~cm}$ was recorded, treatment with Gibberellic acid $\left(\mathrm{GA}_{3}\right) 200$ ppm followed by Gibberellic acid $\left(\mathrm{GA}_{3}\right) 150 \mathrm{ppm}$ $69.30 \mathrm{~cm}$ and Naphthalene Acetic Acid (NAA) $68.86 \mathrm{~cm}$. lowest plant height 54.08 $\mathrm{cm}$ recorded with Cycocel (CCC) $1000 \mathrm{ppm}$. Plant height $64.65 \mathrm{~cm}$ was found in control as compared to other treatment.

In the year 2016 at 150 DAT, the height of the plant was observed to be in the range 64.03 $48.13 \mathrm{~cm}$ as compared to control. The highest plant height $64.03 \mathrm{~cm}$ was recorded treatment with Gibberellic acid $\left(\mathrm{GA}_{3}\right) 200$ ppm followed by Gibberellic acid $\left(\mathrm{GA}_{3}\right) 150 \mathrm{ppm}$ $62.16 \mathrm{~cm}$ and Naphthalene Acetic Acid (NAA) $61.70 \mathrm{~cm}$. lowest plant height 48.13 $\mathrm{cm}$ recorded with Cycocel (CCC), $1000 \mathrm{ppm}$. Plant height $59.87 \mathrm{~cm}$ was found in control as compared to other treatment.

Pooled data was observed to be in the range $67.47-51.11 \mathrm{~cm}$ as compared to control. The highest plant height $67.47 \mathrm{~cm}$ was recorded treatment with Gibberellic acid $\left(\mathrm{GA}_{3}\right) 200$ ppm as compared to lowest plant height 51.11 $\mathrm{cm}$ with Cycocel (CCC), $1000 \mathrm{ppm}$. Plant height $63.35 \mathrm{~cm}$ was found in control as compared to other treatment.

\section{Fresh weight plant $^{-1}$}

Data on the impact of different growth hormones on the fresh weight of plant at different stage of plant growth are presented in the table 2 .

In the year 2015 at 90 DAT, the fresh weight plant $^{-1}$ was observed to be in the range 389.15 280.17 as compared to control. The highest fresh weight plant $^{-1} 389.15$ was recorded treatment with Cycocel (CCC), 1000 ppm followed by Cycocel (CCC) 500 ppm 358.97 and Maleic Hydrazide (MH) 150 ppm 349.34. Lowest fresh weight plant $^{-1} 280.17$ with NAA $50 \mathrm{ppm}$. Fresh weight plant $^{-1} 284.78$ was found in control as compared to other treatment. 
In the year 2016 at 90 DAT, the fresh weight plant $^{-1}$ was observed to be in the range 384.94 - 277.50 as compared to control. The highest fresh weight plant $^{-1} 384.94$ was recorded treatment with Cycocel (CCC) 1000 ppm followed by Cycocel (CCC) 500 ppm 354.66 and Maleic Hydrazide (MH) 150 ppm 346.05 Lowest fresh weight plant ${ }^{-1} 277.50$ with NAA 50 ppm. Fresh weight plant ${ }^{-1} 269.36$ was found in control as compared to other treatment.

Pooled data was observed to be in the range 387.04 - 278.83 as compared to control. The highest fresh weight plant ${ }^{-1} 387.04$ was recorded treatment with Cycocel (CCC) 1000 as compared to lowest fresh weight plant $^{-1}$ 278.83 NAA $50 \mathrm{ppm}$. Fresh weight plant $^{-1}$ 277.07 was found in control as compared to other treatment.

In the year 2015 at 120 DAT, the fresh weight plant $^{-1}$ was observed to be in the range 735.06 - 516.94 as compared to control. The highest fresh weight plant ${ }^{-1} 735.06$ was recorded treatment with Cycocel (CCC) 1000 ppm followed by Cycocel (CCC) 500 ppm 694.93 and Maleic Hydrazide (MH) 150 ppm 658.06 Lowest fresh weight plant ${ }^{-1} 516.94$ with NAA 50 ppm. Fresh weight plant $^{-1} 477.06$ was found in control as compared to other treatment.

In the year 2016-17 at 120 DAT, the fresh weight plant $^{-1}$ was observed to be in the range 694.09 - 495.78 as compared to control. The highest fresh weight plant $^{-1} 694.09$ was recorded treatment with Cycocel (CCC) 1000 ppm followed by Cycocel (CCC) 500 ppm 663.74 and Maleic Hydrazide (MH) 150 ppm 627.64 Lowest fresh weight plant $^{-1} 495.78$ with NAA $50 \mathrm{ppm}$. Fresh weight plant $^{-1}$ 456.62 was found in control as compared to other treatment. Pooled data was observed to be in the range 714.58 - 506.36 as compared to control. The highest Fresh weight plant $^{-1}$
714.58 was recorded treatment with Cycocel (CCC) 1000 as compared to lowest Fresh weight plant $^{-1} 506.36$ NAA 50 ppm. Fresh weight plant $^{-1} 466.84$ was found in control as compared to other treatment.

In the year 2015 at 150 DAT, the fresh weight plant $^{-1}$ was observed to be in the range 777.81- 550.50 as compared to control. The highest fresh weight plant $^{-1} 777.81$ was recorded treatment with Cycocel (CCC), 1000 ppm followed by Cycocel (CCC) 500 ppm 734.82 and Maleic Hydrazide (MH) 150 ppm 669.30. Lowest fresh weight plant $^{-1} 550.50$ with NAA $50 \mathrm{ppm}$. Fresh weight plant $^{-1}$ 541.68 was found in control as compared to other treatment.

In the year 2016 at 150 DAT, the fresh weight plant $^{-1}$ was observed to be in the range 741.94 - 524.29 as compared to control. The highest fresh weight plant $^{-1} 741.94$ was recorded treatment with Cycocel (CCC) 1000 ppm followed by Cycocel (CCC) 500 ppm 726.30 and Maleic Hydrazide (MH) 150 ppm 661.47. Lowest fresh weight plant $^{-1} 524.29$ with NAA 50 ppm. Fresh weight plant $^{-1} 518.80$ was found in control as compared to other treatment.

Pooled data was observed to be in the range 759.88 - 537.40 as compared to control. The highest Fresh weight plant ${ }^{-1} 759.88$ was recorded treatment with Cycocel (CCC) 1000 as compared to lowest fresh weight plant $^{-1}$ 537.40 NAA $50 \mathrm{ppm}$. Fresh weight plant $^{-1}$ 530.24 was found in control as compared to other treatment.

\section{Dry weight of plant (g) plant ${ }^{-1}$}

Data on the impact of different growth hormones on the fresh weight of plant at different stage of plant growth are presented in the table 3 . 
In the year 2015 at 90 DAT, the dry weight plant $^{-1}$ was observed to be in the range 49.5734.75 as compared to control. The highest dry weight plant $^{-1} 49.57$ was recorded treatment with Cycocel (CCC), 1000 ppm followed by Cycocel (CCC) 500 ppm 44.49 and Maleic Hydrazide (MH) 150 ppm 37.89. Lowest dry weight plant $^{-1} 34.75$ with NAA 100 ppm. Dry weight plant $^{-1} 32.56$ was found in control as compared to other treatment.

In the year 2016 at 90 DAT, the dry weight plant $^{-1}$ was observed to be in the range 47.47 33.04 as compared to control. The highest dry weight plant $^{-1} 47.47$ was recorded treatment with Cycocel (CCC) 1000 ppm followed by Cycocel (CCC) 500 ppm 42.74 and Maleic Hydrazide (MH) 150 ppm 36.04. lowest dry weight plant $^{-1} 33.04$ with NAA 100 ppm. Dry weight plant $^{-1} 31.70$ was found in control as compared to other treatment.

Pooled data was observed to be in the range 48.52 - 33.90 as compared to control. The highest dry weight plant $^{-1} 104.33$ was recorded treatment with Cycocel (CCC) 1000 as compared to lowest dry weight plant $^{-1}$ 65.57 NAA 100 ppm. Dry weight plant $^{-1}$ 32.13 was found in control as compared to other treatment.

In the year 2015 at 120 DAT, the dry weight plant $^{-1}$ was observed to be in the range 96.04 65.48 as compared to control. The highest dry weight plant $^{-1} 96.04$ was recorded treatment with Cycocel (CCC), 1000 ppm followed by Cycocel (CCC) 500 ppm 89.95 and Maleic Hydrazide (MH) 150 ppm 80.69. Lowest dry weight plant $^{-1} 65.48$ with NAA 100 ppm. Dry weight plant $^{-1} 63.59$ was found in control as compared to other treatment.

In the year 2016 at 120 DAT, the dry weight plant $^{-1}$ was observed to be in the range 94.89 63.97 as compared to control. The highest dry weight plant $^{-1} 94.89$ was recorded treatment with Cycocel (CCC) 1000 ppm followed by Cycocel (CCC) 500 ppm 89.00 and Maleic Hydrazide (MH) 150 ppm 79.86. lowest dry weight plant $^{-1} 63.97$ with NAA 100 ppm. Dry weight plant $^{-1} 62.07$ was found in control as compared to other treatment.

Pooled data was observed to be in the range 95.47 - 64.73 as compared to control. The highest dry weight plant $^{-1} 95.47$ was recorded treatment with Cycocel (CCC) 1000 as compared to lowest dry weight plant ${ }^{-1} 64.73$ NAA 100 ppm. Dry weight plant ${ }^{-1} 62.83$ was found in control as compared to other treatment.

In the year 2015 at 150 DAT, the dry weight plant $^{-1}$ was observed to be in the range 105.28 - 67.58 as compared to control. The highest dry weight plant $^{-1} 105.28$ was recorded treatment with Cycocel (CCC), 1000 ppm followed by Cycocel (CCC) 500 ppm 90.46 and Maleic Hydrazide (MH) 150 ppm 85.30. lowest dry weight plant ${ }^{-1} 67.58$ with NAA 100 ppm dry weight plant $^{-1} 64.51$ was found in control as compared to other treatment.

In the year 2016 at 150 DAT, the dry weight plant $^{-1}$ was observed to be in the range 103.38- 63.55 as compared to control. The highest dry weight plant ${ }^{-1} 103.38$ was recorded treatment with Cycocel (CCC) 1000 ppm followed by Cycocel (CCC) 500 ppm 88.52 and Maleic Hydrazide (MH) $150 \mathrm{ppm}$ 82.77. Lowest dry weight plant $^{-1} 63.55$ with NAA 100 ppm. Dry weight plant ${ }^{-1} 63.04$ was found in control as compared to other treatment.

Pooled data was observed to be in the range 104.33 - 65.57 as compared to control. The highest Dry weight plant ${ }^{-1} 104.33$ was recorded treatment with Cycocel (CCC) 1000 as compared to lowest Dry weight plant $^{-1} 65.57$ NAA 100 ppm. Dry weight plant ${ }^{-1} 63.78$ was found in control as compared to other treatment. 


\section{Yield attributing parameters}

\section{Fresh weight of tubers (g)plant ${ }^{-1}$}

Data on the impact of different growth hormones on the yield of tuber at harvesting stage are presented in the table 4 .

In the year 2015 at the time of maturity, the Fresh weight of tubers was observed to be in the range 259.26 - 233.51 as compared to control. The highest Fresh weight 259.26 was recorded treatment with Cycocel (CCC), 1000 ppm followed by Cycocel (CCC) 500 ppm 240.83 and Maleic Hydrazide (MH) 150 ppm 234.30. Lowest Fresh weight 233.51 with NAA $100 \mathrm{ppm}$. Fresh weight 232.37 was found in control as compared to other treatment.

In the year 2016 at the time of maturity, the Fresh weight of tubers was observed to be in the range 256.76 - 232.28 as compared to control. The highest Fresh weight 256.76 was recorded treatment with Cycocel (CCC) 1000 ppm followed by Cycocel (CCC) 500 ppm 252.80 and Maleic Hydrazide (MH) 150 ppm 249.67. Lowest Fresh weight 232.28 with
NAA 100 ppm. Fresh weight 226.56 was found in control as compared to other treatment.

Pooled data was observed to be in the range 258.01 - 232.89 as compared to control. The highest Fresh weight 258.01 was recorded treatment with Cycocel (CCC) 1000 as compared to lowest Fresh weight 232.89 NAA $100 \mathrm{ppm}$. Fresh weight 63.78 was found in control as compared to other treatment.

\section{Dry weight of tuber (g) plant ${ }^{-1}$}

Data on the impact of different growth hormones on the yield of tuber at harvesting stage are presented in the table 4 . The year 2015 at the time of maturity, the dry weight of tuber was observed to be in the range 43.20 35.82 as compared to control. The highest Dry weight 43.20 was recorded treatment with Cycocel (CCC), 1000 ppm followed by Cycocel (CCC) 500 ppm 41.50 and Maleic Hydrazide (MH) 150 ppm 40.79 lowest Dry weight 35.82 with NAA $100 \mathrm{ppm}$. Dry weight 33.96 was found in control as compared to other treatment.

Table.1 Influence of growth hormones on plant height $(\mathrm{cm})$ plant $^{-1}$ at different stage of the plant growth

\begin{tabular}{|c|c|c|c|c|c|c|c|c|c|}
\hline \multirow[t]{2}{*}{ Treatments } & \multicolumn{3}{|c|}{90 DAT } & \multicolumn{3}{|c|}{120 DAT } & \multicolumn{3}{|c|}{150 DAT } \\
\hline & 2015 & 2016 & Pooled & 2015 & 2016 & Pooled & 2015 & 2016 & Pooled \\
\hline MH@100 ppm & 46.18 & 45.70 & 45.94 & 57.40 & 51.14 & 54.27 & 59.15 & 53.72 & 56.43 \\
\hline MH @150 ppm & 46.36 & 45.27 & 45.81 & 55.84 & 51.36 & 53.60 & 57.39 & 53.68 & 55.54 \\
\hline CCC @500 ppm & 46.17 & 43.03 & 44.60 & 53.60 & 49.51 & 51.56 & 57.09 & 51.50 & 54.30 \\
\hline CCC@1000 ppm & 45.30 & 42.41 & 43.86 & 52.40 & 45.56 & 48.98 & 54.08 & 48.13 & 51.11 \\
\hline NAA@50 ppm & 49.89 & 46.92 & 48.41 & 65.13 & 57.11 & 61.12 & 68.76 & 60.07 & 64.41 \\
\hline NAA@100 ppm & 50.41 & 49.93 & 50.17 & 65.20 & 59.63 & 62.42 & 68.86 & 61.70 & 65.28 \\
\hline GA3 @150 ppm & 51.54 & 51.08 & 51.31 & 65.46 & 60.34 & 62.90 & 69.30 & 62.16 & 65.73 \\
\hline $\mathbf{G A}_{3} @ 200$ ppm & 53.07 & 51.31 & 52.19 & 66.22 & 61.06 & 63.64 & 70.90 & 64.03 & 67.47 \\
\hline CONTROL & 49.34 & 47.18 & 48.26 & 63.87 & 56.80 & 60.33 & 66.82 & 59.87 & 63.35 \\
\hline Mean & 62.61 & 60.40 & 61.51 & 77.87 & 70.36 & 74.12 & 81.77 & 73.55 & 77.66 \\
\hline SEm \pm & 1.55 & 1.83 & 1.69 & 2.33 & 1.66 & 2.00 & 2.60 & 1.50 & 2.05 \\
\hline CD at $5 \%$ & 4.64 & 5.49 & 5.07 & 7.00 & 4.99 & 5.99 & 7.80 & 4.49 & 6.15 \\
\hline
\end{tabular}


Table.2 Influence of growth hormones on fresh weight of plant (g) at different stage of the plant growth

\begin{tabular}{|c|c|c|c|c|c|c|c|c|c|}
\hline \multirow[t]{2}{*}{ Treatments } & \multicolumn{3}{|c|}{90 DAT } & \multicolumn{3}{|c|}{120 DAT } & \multicolumn{3}{|c|}{150 DAT } \\
\hline & 2015 & 2016 & Pooled & 2015 & 2016 & Pooled & 2015 & 2016 & Pooled \\
\hline MH @100 ppm & 337.23 & 333.39 & 335.31 & 622.64 & 603.59 & 613.12 & 629.79 & 621.13 & 625.46 \\
\hline MH@150 ppm & 349.34 & 346.05 & 347.69 & 658.06 & 627.64 & 642.85 & 669.30 & 661.47 & 665.38 \\
\hline CCC@500 ppm & 358.97 & 354.66 & 356.82 & 694.93 & 663.74 & 679.33 & 734.82 & 726.30 & 730.56 \\
\hline CCC@1000 ppm & 389.15 & 384.94 & 387.04 & 735.06 & 694.09 & 714.58 & 777.81 & 741.94 & 759.88 \\
\hline NAA @50 ppm & 280.17 & 277.50 & 278.83 & 516.94 & 495.78 & 506.36 & 550.50 & 524.29 & 537.40 \\
\hline NAA@100 ppm & 285.79 & 281.16 & 283.47 & 527.91 & 506.14 & 517.02 & 569.01 & 545.33 & 557.17 \\
\hline GA3@150 ppm & 298.65 & 295.72 & 297.18 & 543.36 & 524.18 & 533.77 & 580.85 & 560.50 & 570.68 \\
\hline GA3 $@ 200$ ppm & 313.00 & 308.89 & 310.95 & 603.23 & 595.54 & 599.39 & 608.34 & 598.11 & 603.23 \\
\hline CONTROL & 284.78 & 269.36 & 277.07 & 477.06 & 456.62 & 466.84 & 541.68 & 518.80 & 530.24 \\
\hline Mean & 413.87 & 407.38 & 410.62 & 768.46 & 738.19 & 753.32 & 808.87 & 785.41 & 797.14 \\
\hline SEm \pm & 10.47 & 5.33 & 7.90 & 10.50 & 17.47 & 13.99 & 8.66 & 14.64 & 11.65 \\
\hline CD at $5 \%$ & 31.39 & 15.97 & 23.68 & 31.48 & 52.37 & 41.93 & 25.97 & 43.88 & 34.92 \\
\hline
\end{tabular}

Table.3 Influence of growth hormones on dry weight of plant $(\mathrm{g})$ at different stage of the plant growth

\begin{tabular}{|c|c|c|c|c|c|c|c|c|c|}
\hline \multirow[t]{2}{*}{ Treatments } & \multicolumn{3}{|c|}{90 DAT } & \multicolumn{3}{|c|}{120 DAT } & \multicolumn{3}{|c|}{150 DAT } \\
\hline & 2015 & 2016 & Pooled & 2015 & 2016 & Pooled & 2015 & 2016 & Pooled \\
\hline MH@100ppm & 37.82 & 36.04 & 36.93 & 77.22 & 75.93 & 76.57 & 81.41 & 79.04 & 80.22 \\
\hline MH@150 ppm & 37.89 & 36.31 & 37.10 & 80.69 & 79.86 & 80.28 & 85.30 & 82.77 & 84.03 \\
\hline CCC @500 ppm & 44.49 & 42.74 & 43.61 & 89.95 & 89.00 & 89.47 & 90.46 & 88.52 & 89.49 \\
\hline CCC@1000 ppm & 49.57 & 47.47 & 48.52 & 96.04 & 94.89 & 95.47 & 105.28 & 103.38 & 104.33 \\
\hline NAA @50 ppm & 34.75 & 33.04 & 33.90 & 65.48 & 63.97 & 64.73 & 67.58 & 63.56 & 65.57 \\
\hline NAA@100 ppm & 35.02 & 33.52 & 34.27 & 67.09 & 66.23 & 66.66 & 69.18 & 65.43 & 67.31 \\
\hline GA3 @150 ppm & 36.43 & 34.74 & 35.58 & 69.41 & 67.93 & 68.67 & 74.55 & 71.47 & 73.01 \\
\hline $\mathbf{G A}_{3} @ 200$ ppm & 37.29 & 35.56 & 36.42 & 75.52 & 71.78 & 73.65 & 79.46 & 77.40 & 78.43 \\
\hline CONTROL & 32.56 & 31.70 & 32.13 & 63.59 & 62.07 & 62.83 & 64.51 & 63.04 & 63.78 \\
\hline Mean & 49.40 & 47.30 & 48.35 & 97.85 & 95.95 & 96.90 & 102.53 & 99.23 & 100.88 \\
\hline SEm \pm & 1.62 & 1.77 & 1.69 & 3.00 & 3.28 & 3.14 & 4.00 & 2.89 & 3.45 \\
\hline CD at $5 \%$ & 4.85 & 5.30 & 5.07 & 8.98 & 9.82 & 9.40 & 11.99 & 8.68 & 10.33 \\
\hline
\end{tabular}


Table.4 Influence of growth hormones on yield attributes at the time of maturity

\begin{tabular}{|c|c|c|c|c|c|c|c|c|c|}
\hline \multirow[t]{2}{*}{ Treatments } & \multicolumn{3}{|c|}{ Fresh weight of Tubers (g) plant ${ }^{-1}$} & \multicolumn{3}{|c|}{ Dry weight of Tubers (g)plant ${ }^{-1}$} & \multicolumn{3}{|c|}{ Yield of Tubers (t) $\mathrm{ha}^{-1}$} \\
\hline & 2015 & 2016 & Pooled & 2015 & 2016 & Pooled & 2015 & 2016 & Pooled \\
\hline MH@100 ppm & 247.26 & 246.83 & 247.04 & 39.43 & 38.82 & 39.13 & 2.40 & 2.29 & 2.34 \\
\hline MH @150 ppm & 250.03 & 249.67 & 249.85 & 40.79 & 40.20 & 40.50 & 2.47 & 2.33 & 2.40 \\
\hline CCC@500 ppm & 254.31 & 252.80 & 253.56 & 41.50 & 40.71 & 41.11 & 2.56 & 2.45 & 2.51 \\
\hline CCC@1000 ppm & 259.26 & 256.76 & 258.01 & 43.20 & 42.66 & 42.93 & 2.65 & 2.54 & 2.60 \\
\hline NAA @50 ppm & 233.51 & 232.28 & 232.89 & 36.06 & 34.56 & 35.31 & 2.08 & 1.97 & 2.03 \\
\hline NAA@100 ppm & 236.63 & 235.86 & 236.25 & 37.39 & 35.65 & 36.52 & 2.17 & 2.06 & 2.11 \\
\hline GA3 @150 ppm & 238.87 & 238.57 & 238.72 & 35.82 & 35.74 & 35.78 & 2.21 & 2.10 & 2.16 \\
\hline GA3 @200 ppm & 241.15 & 240.10 & 240.63 & 37.53 & 37.12 & 37.33 & 2.34 & 2.19 & 2.27 \\
\hline CONTROL & 232.37 & 226.56 & 229.47 & 33.96 & 33.63 & 33.80 & 2.06 & 1.95 & 2.01 \\
\hline Mean & 313.34 & 311.35 & 312.34 & 49.39 & 48.44 & 48.91 & 2.99 & 2.84 & 2.92 \\
\hline $\mathrm{SEm} \pm$ & 4.73 & 5.30 & 5.01 & 1.58 & 1.42 & 1.45 & 0.05 & 0.05 & 0.05 \\
\hline CD at $5 \%$ & 14.19 & 15.87 & 15.03 & 4.73 & 4.25 & 4.34 & 0.16 & 0.15 & 0.15 \\
\hline
\end{tabular}


In the year 2016 at the time of maturity, the Dry weight of tuber was observed to be in the range 42.66- 34.56 as compared to control. The highest Dry weight 42.66 was recorded treatment with Cycocel (CCC) 1000 ppm followed by Cycocel (CCC) 500 ppm 41.50 and Maleic Hydrazide (MH) 150 ppm 40.79. lowest Dry weight 34.56 with NAA 100 ppm. Dry weight 33.63 was found in control as compared to other treatment.

Pooled data was observed to be in the range 42.93 - 35.31 as compared to control. The highest Dry weight 42.93 was recorded treatment with Cycocel (CCC) 1000 as compared to lowest Dry weight 35.31 NAA $100 \mathrm{ppm}$. Dry weight 33.80 was found in control as compared to other treatment.

\section{Yield of tuber (t) $\mathrm{ha}^{-1}$}

Data on the impact of different growth hormones on the yield of tuber at harvesting stage are presented in the table 4 .

In the year 2015 at the time of maturity, the yield of tuber was observed to be in the range 2.65-2.08 as compared to control. The highest yield of tuber 2.65 was recorded treatment with Cycocel (CCC), 1000 ppm followed by Cycocel (CCC) 500 ppm 2.56 and Maleic Hydrazide (MH) 150 ppm 2.47 lowest yield of tuber 2.08 with NAA $100 \mathrm{ppm}$. Yield of tuber 2.06 was found in control as compared to other treatment.

In the year 2016 at the time of maturity, the yield of tuber was observed to be in the range 2.54 - 1.97 as compared to control. The highest yield of tuber 2.54 was recorded treatment with Cycocel (CCC) 1000 ppm followed by Cycocel (CCC) 500 ppm 2.45 and Maleic Hydrazide (MH) 150 ppm 2.33. lowest yield of tuber 1.97 with NAA 100 ppm. Yield of tuber 1.95 was found in control as compared to other treatment.
Pooled data was observed to be in the range $2.60-2.03$ as compared to control. The highest yield of tuber 2.60 was recorded treatment with Cycocel (CCC) 1000 as compared to lowest yield of tuber 2.03 with NAA 100 ppm. Yield of tuber 2.01 was found in control as compared to other treatment.

The studies on morphological parameters, pooled data (2015 and 2016) at 150 day after transplanting (DAT) revealed that application of Cycocel @1000 ppm resulted in reduction of plant height $(\mathrm{cm})$ plant $^{-1}(51.11)$, increase fresh weight of plant (g) plant ${ }^{-1}(759.88)$ and dry weight of plant (g) plant ${ }^{-1}$ (104.33) followed by Cycocel @ 500 ppm respectively (54.30, 730.56, 89.49) as campier to control $(63.35,530.24,63.78)$. The working on yield attributing parameters, pooled data (2015 and 2016) at harvesting revealed that application of Cycocel @1000 ppm resulted in increased fresh weight of tuber $(\mathrm{g})$ plant $^{-1}$ (258.01), dry weight of tuber $(\mathrm{g})$ plant $^{-1}$ (42.93), and yield of tuber $(\mathrm{t}) \mathrm{ha}^{-1}$ (2.60) followed by Cycocel @ 500 ppm respectively $(240.27,253.56$ and 2.51) as compare to control $(205.18,229.47$ and 2.01) Similar finding were observed by Sunil Kumar (2005) and Swamy (2006) in coleus.

\section{Acknowledgments}

We are thankful to the Department of Plant Physiology, College of Agriculture, Jabalpur (JNKVV) for providing lab facilities for the analysis. And with thanks for the farmer for conducted of experiments

\section{References}

Panse, V.G. and Sukhatme, P.V. (1989). Statical methods for Agriculture workers. ICAR New Delhi, pp. 97-105.

Swamy, R. (2006). Influence of growth regulator and productivity of Coleus forskohlii (Willd) Briq. 
Sunil Kumar, G.S. (2005). Influence of organic and growth regulator and yield of coleus. Ph. D. Thesis. University of Agricultures Sciences, Dharwad.

Shah, V., Bhat, S. V. Bajwa, B. S., Domacur, H. and De souza, N. J. (1980). The occurrence of forskolin in Labiatae. Plant Med., 39: 183-185

Valdes, L. J., Mislankar, S. G. and Paul, A. G. (1987). Colius barbatus (Lamiaceae) and the potential new drug forskolin (Colenol). Eco. Bot., 41: 474-483.

\section{How to cite this article:}

Choudhary, A. K., S. D. Upadhyaya and Sharma, A. 2020. Influence of Plant Growth Hormones on Morphology and Yield of Patharchur (Coleus forskohlii (Willd) Briq). Int.J.Curr.Microbiol.App.Sci. 9(10): 3556-3565. doi: https://doi.org/10.20546/ijcmas.2020.910.410 